\title{
Developmental Prospects of Women Entrepreneurs in Azerbaijan and an Analysis of the Problems They Face
}

\author{
Assoc. Prof. Fariz Ahmadov ${ }^{1}$, Res. Asst. Ulkar Zeynalova ${ }^{2}$, Res. Asst. Ulkar Bayramova ${ }^{3}$, Res. Asst. Orxan Quluzade ${ }^{4}$ \\ Azerbaijan State University of Economic (UNEC), Azerbaijan
}

\begin{abstract}
The greater the size of entrepreneurship in a country's economy, the economy of that country is considered so strong. For this reason, many developing countries pay great attention to entrepreneurship in the process of the transition to a market economy. One of the main problems facing the transition to a market economy is the creation of a suitable work environment and a business environment. The main challenge for these countries is to reduce poverty and achieve prosperity. One of such strategies in the modern world is the growth and development of women's entrepreneurship. It is great importance to explore the subject in the country, which separates the Soviet Union from a planned economy to a market economy, which is a country where entrepreneurial ideas have begun to be formed.

$50.1 \%$ of the population of Azerbaijan Republic, which is one of the countries where market economy is newly established, consists of females. This study examines their entrepreneurial activities, their role in the economy and the problems they face.

The article discusses the possibilities of applying the experience of countries in this field in the world. In addition, the current situation of women's entrepreneurship in Azerbaijan, development prospects, the role of women in the country's economy, the problems faced by women entrepreneurs have been investigated and analyzed. For this purpose, a survey was conducted for women entrepreneurs, and analyzes were performed using IBM SPSS Statistics 24.0. At the end, suggestions were made based on theoretical and statistical indicators and analyzes, and a developmental perspective was shown.
\end{abstract}

Keywords:Terms-entrepreneurship,women's entrepreneurship, development of women's entrepreneurship

\section{INTRODUCTION}

The entrepreneurship is one of the most important means in the employment growth, the improvement of the level of prosperity, the poverty reduction in society, and generally in the development of the national economy.

Economic and social development requires entrepreneurial agents, therefore a growing interest both on the part of government authorities for encouraging entrepreneurship, and researchers with the ultimate objective of uniting understanding of this phenomenon [1].

Entrepreneurship means the creation of new businesses and the activity of introducing new products and processes into existing companies [2], business entity creates jobs, intensifies competition and drives innovation.

There are some perspectives of studies related to the entrepreneurship. We can see changes in their approaches by passing time, ranging from an economic approach, with Schumpeter, to a behavioral and managerial approach, with Drucker, McClelland and other current theorists, who seek to understand the phenomenon from a more holistic viewpoint, such as corporate entrepreneurship studies and gender studies [3].

Women entrepreneurship is functional in the matters such as creation of new work places, the promotion of economic and social development, and the activation of human capital assets, so its research is of great importance. Although the matter we mentioned is very urgent, the wide researches have not been carried out in Azerbaijan, that's why it is needed to research this matter, and to carry out analyses. The immediacy of the problem is of great importance to research it in Azerbaijan as a country separating from the Soviet Union, passing from the planned economy to the market economy, and where the business ideas and thoughts begin to form newly.

The purpose of the research is to reveal the current state of the women entrepreneurship in Azerbaijan, its development prospects, the role in country economy, and the issues confronted by the women entrepreneurs. For this purpose, the questionnaire has been applied to 316 respondents, and the analyses have been carried out through the program IBM SPSS Statistics 24.0.

Learning of the women entrepreneurship issues through this research, to draw attention to the problem areas, the ways of their solution, as well as, the ways of development of the women entrepreneurship have been studied. 
International Conference on Research in

\section{Business, Management \& Economics}

\section{Literature Review}

Entrepreneurship is an important part of the transformation from a centralised planned economy to a market economy [4]

It is now widely recognized that entrepreneurial talent is important for economic growth, innovation and job creation although entrepreneurship has been largely ignored or treated in a highly simplified way in endogenous growth theory, [5] [6]

As mentioned by Berg [7], "the material and the socio-cultural contexts in which entrepreneurship takes place, are also gender-related". Since at the economic level scholars can claim that women's entrepreneurial activity can make a significant contribution towards GDP [8], women entrepreneurs' contribution is affected by specific socio-cultural contexts.

The approach of the present research is behavioral in nature [9], and criticizes the rational view according to which entrepreneurship is a universal phenomenon and immune to gender.

Academics and practitioners emphasize that female entrepreneurship plays a significant role within the context of socio-economic development [10] [11]. Women entrepreneurs create jobs and innovation, and contribute to the GDP of various economies not less than their male counterparts. However, the contributions women entrepreneurs make to society are even more compelling. There is growing evidence that women are more likely to reinvest their profits in education, their family and community [12]. Moreover, the studies showed that women are more eager to start businesses with both social and economic goals and even hybrid ventures [13]. Many studies provide evidence which says about the prominent character of female entrepreneurship in relation to poverty reduction [14] and tend to point out its huge impact on local communities and their surroundings [15].

Women play a significant role in both business creation and generation of workplaces at global level, by contributing effectively to the economy, despite their contribution remains mostly hidden because of the gender bias that exists in both the labour force and society [16].

However, characteristics of women that are thought to be typical of their sex can comprise a major hinder to their career choices, as well as their decision to involve in entrepreneurship. Additionally, as stated by Marlow and Patton [17], associating stereotypical behaviors with either the masculine or the feminine often serves to privilege the former over the latter, thus supporting a hierarchical valuation of habits and characteristics

\section{ICRBME}

The research practice related to the women entrepreneurship from the different world researches and their results have been mentioned in the following TABLE I

\section{TABLE I:}

1. LeylaSarfaraz, NezameddinFaghih and ArmaghanAsadiMajd
(2014)

The research work analyses that the degree of entrepreneurship's impact on the economy depends on numerous factors, including the quality, gender composition, and type of entrepreneurial activity. Gender equality and female entrepreneurship are main factors in economic development. This paper studies relations between gender-related economic development and women entrepreneurial activity. They showed the relationship between gender-related development indices (introduced by the United Nations) and different stages of women entrepreneurial activity (created by Global Entrepreneurship Monitor, GEM). It was noted that female entrepreneurial activity is not significantly correlated with gender equality [18].

\section{Jennifer E. Jennings, Candida G. Brush (2013)}

The research was based on three main goals in this study. The first goal was to document the development of the work known as women's entrepreneurship research. The second was to evaluate the contributions of this work and third was to discuss both challenges as well as opportunities for scholarship on female entrepreneurs. Another point was that despite many women entrepreneurship research has ostensibly focused on topics similar to those studied by general entrepreneurship scholars. The collected work about female entrepreneurs revealed that entrepreneurship is a gendered phenomenon, that entrepreneurial activity is embedded in families and can result from necessity as well as opportunity, and that entrepreneurs often pursue goals beyond economic gain [19].

\section{Ekesionye E. N and Okolo A. N (5 January, 2012)}

Investigated women empowerment and participation in economic activities as tools for self-reliance and development of the Nigerian society. This study concludes that major economic activities were crop farming, trading, craft, and food processing, hairdressing and poultry production. These economic

activities were funded by women on account of personal savings, family, charities, cooperative societies,

loan and credits. Absence

of government support, corruption, cultural restrictions, family burden, husband influence and illiteracy were recorded as obstacles faced by women in economic activities. Provision of sustainable land tenure system, soft loans and credits, training Andre-training programmers, establishment of co-operative society would increase women participation in economic activities and societal development in Nigeria [20]. 


\section{International Conference on Research in}

\section{Business, Management $\&$ Economics}

\begin{abstract}
4. Syed Shah Alam, Mohd Fauzi MohdJani, Nor Asiah Omar (May 2011)

Searched the key factors which affects the success of women entrepreneurs in Southern region in Malaysia. The findings suggested that family support, social ties and internal motivation affect positively and significantly to the success of women entrepreneurs in the small business. It had also shown that in the past, women rarely went into business not because of lack of interest but because of lack of opportunities A study done in the United Kingdom concluded that the gap between male and female entrepreneurs in the region was disappearing due to the wide opportunities which are being created all over the world for women entrepreneurs to open up businesses [21].
\end{abstract}

\section{Hackler, Darrene, Harpel and Mayer, Heike (2008)}

Performed a study on finding the relationship between elements of human capital and self-employment among women. The study showed that self-employed women differ on most human capital variable as compared to the salary and wage earning women and the fact that the education attainment level is faster for self employed women than that for other working women. The percentage of occupancy of managerial job is found to be comparatively higher in case of self employed women as compared to other working women. Self-employed men and women differ little in education, experience and preparedness. However, the main difference lies in occupational and industry experience. The percentage of population holding management occupation is lower for self employed women as compared to self-employed men. Also the participation levels of self-employed women are found to be less than of self-employed men in industries like communication, transportation, wholesale trade, manufacturing and construction [22].

\section{Debra Efroymson, Buddhadeb Biswas, and Shakila Ruma (September 2007)}

In their research attempted to quantify what work women do and the amount of time they spend working, estimate the economic value of that work, and thereby assess the contributions women make to the country 's social development through their unpaid work. This study concludes that women are involved in a tremendous amount of work that has significant value to family, society, and the nation. Men are able to engage in paid labor because of all the work that women do in the home: cleaning the home, washing clothes, preparing food, washing dishes, and engaging in all the task involved in bearing and raising children [23].

\section{C. Mirjam van Praag, Peter H. Versloot, (August 2007)}

Examined the claim that entrepreneurship has important economic value. Hence, a systematic review provided the answers to the question: What is the contribution of entrepreneurs to the economy in comparison to non-entrepreneurs? In this study, there is a contribution of entrepreneurs to the economy based on four measures that had been studied empirically are, (i) employment generation and dynamics, (ii) innovation, and (iii) productivity and growth, relative to the contributions of the entrepreneurs 'counterparts, i.e. the 'control group', (iv) the role of entrepreneurship in increasing individuals 'utility levels. This study concluded that entrepreneurs have a very important and specific function in the economy. They engender relatively much employment creation, productivity growth and produce and commercialize high quality innovations. However, women cannot be neglected as they account for are relatively high value of GDP, a less volatile and more secure labor market, higher paid jobs and a greater number of innovations and they have a more active role in the adoption of innovations [24].

\section{Glen Cain's (1966)}

The following key findings were revealed: Higher unemployment negatively affected women 's labour force participation rate. The statistics said that wives of unemployed men were more likely to be in the labour force to support family income, than those of employed men. He also analyzed that wage was not as strong a positive determinant of women 's choice to join the labour force. However, wage was still a stronger determinant in comparison to the proportion of wife 's earnings in family income (which itself affects the participation rate in a negative manner). Other important determinants were market wage rate for other family members and number of young children in the household which negatively affected women 's decision to join the labour force [25].

\section{Torch Burch (Nov 18th 2013),}

It is assumable that women entrepreneurs see the world through a different lens and, in turn, do things differently. Though the women are operating new businesses, yet they face a huge equality gap. Only in seven countries like Panama, Thailand, Ghana, Ecuador, Nigeria, Mexico and Uganda women take part in business on equal level as men; in some countries, like Pakistan, they rarely take part at all. Even when women are active business owners, they do not reach their potential. Women face particular hurdles, from a lack of collateral to discriminatory regulations and ingrained gender bias when the matters relates to finance. Financial institutions must do a better job of banking on women 's potential by thinking creatively and forging partnerships, to give more women an access to the resources that can enable them to start up or scale up. Narrowing the gender gap in employment will increase global income per person.

(Torch Burch, 2013) [26]

\section{Tambunan, Tulus, (2009)}

In his article mainly focused on women entrepreneurs in small and medium enterprises based on data analysis and review of recent basic literature. This study established that in developing countries of Asia, Small and Medium Entrepreneurship is gaining overwhelming importance; more than $95 \%$ of all firms in all sectors on average per country. The study also defined the fact that women entrepreneurs are represented in this region relatively low due to factors like low level of education, lack of capital and cultural or religious constraints[27]. 


\section{International Conference on Research in}

\section{Business, Management \& Economics}

\section{DESIGGN/METHODOLOGY/APPROACH}

The statistical factors of the country related to the women entrepreneurship, the international researches have been researched theoretically and systematically. At the same time, the questionnaire have been applied to 316 women entrepreneurs and T-test, Anova, Descriptive Statistics analysis have been carried out in the program IBM SPSS Statistics 24.0.

\section{WOMEN ENTREPRENEURSHIP IN} AZERBAIJAN

The Republic of Azerbaijan is an independent state with 86.6 thousand $\mathrm{km} 2$ territory, with 9 million populations. 4938000 persons are man, and 4960100 are women according to the reports of the beginning of the 2018th year[28]. The conflicts between Azerbaijan and Armenia since 1990 were resulted with the cease-fire in May of 1994. In the result of the economic and technological changes happening in the transition stage have offered some new economic opportunities. But not every man and woman has derived benefit equally from the economic growth. The society members of both

\section{ICR $B$ ME}

genders should understand their opportunities and use them in order to achieve the efficiency of the economic and social development, and to derive benefit from the economic development and growth. It is impossible to gain it without provision the women participation in the social, economic, political and cultural life of the society (National report on women entrepreneurship in Azerbaijan [29].

Interest in researching entrepreneurship has been growing recently. It has been proven that entrepreneurship has a positive impact on economic growth and development.

The transition process has undoubtedly resulted in profound and dramatic changes to the economic, political and social landscapes in the former countries of the Soviet empire. There was the severe crisis in the economy of the Republic of Azerbaijan upon the breakup of the USSR, the occupational level was decreased distinctly. The slowdown in economy was stopped in the second half of the 1990th year in Azerbaijan, and the interest of population in small and medium business was increased. During the period after the independence,

\begin{tabular}{|c|c|c|c|c|c|}
\hline \multicolumn{6}{|c|}{ Development stages of the entrepreneurship } \\
\hline \multicolumn{2}{|c|}{ Stages } & Features & Results & $\begin{array}{c}\text { Demands of the economic } \\
\text { growth }\end{array}$ & Stages \\
\hline \multicolumn{2}{|c|}{$\begin{array}{c}\text { Stage before } \\
1993\end{array}$} & $\begin{array}{c}\text { - Delays in the realization of } \\
\text { reforms } \\
\text { - Lack of system in the episodic } \\
\text { measures taken }\end{array}$ & $\begin{array}{l}\text { - Reduction of the } \\
\text { developmental } \\
\text { parameters level } \\
\text { - Domination of } \\
\text { instability in the } \\
\text { financial and } \\
\text { manufacturing fields }\end{array}$ & $\begin{array}{c}\text { - Necessity to begin the } \\
\text { systematized reforms in the } \\
\text { direction of market economy } \\
\text { - Realization of privatization } \\
\text { - Formation of state protection } \\
\text { system of entrepreneurship } \\
\text { creation }\end{array}$ & Stage before 1993 \\
\hline \multirow{2}{*}{$\begin{array}{c}\text { Years } \\
1993- \\
2002\end{array}$} & $\begin{array}{c}\text { Years } \\
1993- \\
1996\end{array}$ & $\begin{array}{c}\text { - Provision of necessary } \\
\text { conditions for real reforms } \\
\text { - Achieving the political and } \\
\text { macroeconomic stability } \\
\text { - First measures in the direction } \\
\text { of entrepreneurship creation }\end{array}$ & $\begin{array}{l}\text { Prevention of GDP } \\
\text { reduction } \\
\text { - Provision of the } \\
\text { minimum level of } \\
\text { inflation }\end{array}$ & $\begin{array}{l}\text { Speed-up of reforms } \\
\text { realization on basis formed }\end{array}$ & Years 1993-1996 \\
\hline & $\begin{array}{l}\text { Years } \\
1996- \\
2002\end{array}$ & $\begin{array}{c}\text { - Formation of state protection } \\
\text { system for entrepreneurship } \\
\text { development } \\
\text { - Privatization } \\
\text {-Structural change in } \\
\text { management }\end{array}$ & $\begin{array}{c}\text {-Growth dynamics of } \\
\text { the main } \\
\text { macroeconomic } \\
\text { parameters } \\
\text { Strong growth of } \\
\text { the business entities } \\
\text { number } \\
\text { - Foreign investments } \\
\text { flow }\end{array}$ & $\begin{array}{l}\text { - Realization of the structural } \\
\text { changes in area, regional and } \\
\text { technological point of view } \\
\text { with the purpose of complete } \\
\text { realization of the country } \\
\text { potential }\end{array}$ & Years 1996-2002 \\
\hline \multicolumn{2}{|c|}{$\begin{array}{c}\text { Years } \\
\text { 2002-2015 }\end{array}$} & $\begin{array}{l}\text { - Fundamental changes in the } \\
\text { state protection system of } \\
\text { entrepreneurship development: } \\
\text { - financial supply } \\
\text { - state regulation } \\
\text { - infrastructure } \\
\text { - protection of rights } \\
\text { - development of human capital }\end{array}$ & $\begin{array}{c}\text { - Production oriented } \\
\text { development } \\
\text { propensity in the } \\
\text { entrepreneurship } \\
\text { - Reconstruction of } \\
\text { economic activity in } \\
\text { the regions } \\
\text { - Strengthening the } \\
\text { position of the } \\
\text { entrepreneurs in the } \\
\text { society }\end{array}$ & $\begin{array}{c}\text { - Employment supply } \\
\text { Realization of the regional } \\
\text { potential: } \\
\text { - industry } \\
\text { - agrarian sphere } \\
\text { - tourism } \\
\text { - Realization of export } \\
\text { potential } \\
\text { - Formation and development } \\
\text { of innovation } \\
\text { entrepreneurship }\end{array}$ & Years 2002-2015 \\
\hline
\end{tabular}




\section{Business, Management \& Economics}

\begin{tabular}{|c|c|c|c|c|}
\hline & & $\begin{array}{l}\text { Study of the young } \\
\text { talents in the } \\
\text { advanced countries } \\
\text { with the purpose of } \\
\text { supply the personnel } \\
\text { proper to the } \\
\text { developed economy }\end{array}$ & & \\
\hline $\begin{array}{l}\text { Stages after the } \\
\quad \text { year } 2015\end{array}$ & $\begin{array}{c}\text { - Fundamental reforms in the } \\
\text { direction of development of the } \\
\text { non-oil sector: } \\
\text { - licensing } \\
\text { - cessation of inspections } \\
\text { - industrial or Technologies parks, } \\
\text { industrial regions } \\
\text { - formation and support of export } \\
\text { and investment } \\
\text { - STRATEGIC ROAD MAPS } \\
\text { - support of local production due } \\
\text { to the grants } \\
\text { - Place of the social projects in } \\
\text { the centre of attention }\end{array}$ & $\begin{array}{l}\text { - Rating advance of } \\
\text { the country in the } \\
\text { international reports } \\
\text { - High results on non- } \\
\text { oil industry in the } \\
\text { economy, especially } \\
\text { in export } \\
\text { - Sharp decrease in } \\
\text { the number of the } \\
\text { licenses and } \\
\text { documents required } \\
\text { connected with it } \\
\text { - Cessation of the } \\
\text { inspections carried } \\
\text { out in the field of } \\
\text { entrepreneurship up } \\
\text { to } 2021 .\end{array}$ & $\begin{array}{l}\text { - Electronization of services } \\
\text { rendered to the entrepreneurs } \\
\text { - Production of the competitive } \\
\text { and value-added products } \\
\text { - Regular valuation of the } \\
\text { reforms realization }\end{array}$ & $\begin{array}{l}\text { Stages after the year } \\
2015\end{array}$ \\
\hline
\end{tabular}

Source: Ministry of Economy of Azerbaijan 2014 [30].

As it is seen in the TABLE II, the works in the direction of the economic progress, the substantial reforms and business support have been accelerated since 1993 in the Republic of Azerbaijan. The improvements such as prevention of GDP reduction, interest in entrepreneurship, and the inward investment to the country have been taken place in the results of the reforms carried out. The break of inspection, the severe reduction of the Licenses and documents required connected with it have been observed with the purpose of supporting the entrepreneurship since 2015. In recent years the improvement was happened significantly in the labor market in the result of the reforms carried out in the country economy. In recent years, the relative share of the women among the jobless people was decreased, and it was 36, 3 percent in 2017 compared with 51, 6 percent in 2005. The number of the economic active population was 5073, 8 thousand persons according to the information of the 2017th year, and the number of the women engaging in economy was 2319, 3 thousand persons [28].

Although studies on female entrepreneurship have been conducted since the 1970s around the world and addressed diverse topics, highlighting the profile of women entrepreneurs [31]. But the women entrepreneurship began to develop in Azerbaijan after getting independence.

It was intended to open 5183 new work places due to the privileged credits extended to the women entrepreneurs during the years 2002-2015, as well as, 255 new work places due to the credits extended during 6 months of the 2016th year. The participation of women entrepreneurs are always provided in the measures taken abroad with the purpose of researching the international experience during the entrepreneurial activity. So, according to the memorandum signed between the Ministry of Economy of the Republic of Azerbaijan and the Federal Ministry of Economic Affairs and Technology, the country entrepreneurs including 57 women entrepreneurs from 277 entrepreneurs and 3 women entrepreneurs from 21 entrepreneurs year were sent to the advanced training courses in Germany within the program "Of advanced training of staff in the field of business management" in the I half year of the 2016th.

$50,1 \%$ of the population are women in the Republic of Azerbaijan, and the number of women capable to work is 3349.7 thousand persons according to the calculations of the 2018th year. The number of the women engaging in private entrepreneurship is 170934 persons as reported by the State Statistical Committee of Azerbaijan [28]. 


\section{International Conference on Research in}

\section{Business, Management \& Economics}

TABLE III: GENDER DISTRIBUTION OF PRIVATE ENTREPRENEURS ON ACTIVITY TYPES AT THE DATE OF JANUARY 01, 2018 (PERSON AND GENDER DISTRIBUTION, TOTALLY IN PERCENT)

\begin{tabular}{|l|l|l|l|l|}
\hline Types of activity & Women & \multicolumn{2}{l|}{ Men } \\
\cline { 2 - 4 } & number & percent & number & percent \\
\hline Agriculture, forest industry and fishery & 60227 & 35.2 & 162626 & 26.1 \\
\hline Mining industry & 30 & 0.0 & 642 & 0.1 \\
\hline Processing industry & 2932 & 1.7 & 14222 & 2.3 \\
\hline $\begin{array}{l}\text { Electric power, gas and steam production, distribution and } \\
\text { supply }\end{array}$ & 5 & & \\
\hline Water supply, wastewater treatment and processing & 24 & 0.0 & 57 & 0.0 \\
\hline Construction & 114 & 0.1 & 5928 & 0.0 \\
\hline Commerce; repair of the means of transport & 41641 & 24.4 & 159480 & 25.6 \\
\hline Transport and storage industry & 1140 & 0.7 & 83434 & 13.4 \\
\hline Tourists accommodation and public catering & 5499 & 3.2 & 31980 & 5.1 \\
\hline Information and communication & 1128 & 0.7 & 5341 & 0.9 \\
\hline Financial and insurance activity & 419 & 0.2 & 1300 & 0.2 \\
\hline Operations related to real estate & 3359 & 2.0 & 8794 & 1.4 \\
\hline Professional, scientific and technical activity & 4520 & 2.6 & 8896 & 1.4 \\
\hline Delivering the administrative and ancillary services & 898 & 0.5 & 2023 & 0.3 \\
\hline Education & 3353 & 2.0 & 1891 & 0.3 \\
\hline Delivering of health and social services for population & 935 & 0.5 & 1598 & 0.3 \\
\hline Activity in the field of recreation, entertainment and art & 1221 & 0.7 & 9649 & 1.5 \\
\hline Provision of services in other fields & 38414 & 22.5 & 110740 & 17.8 \\
\hline $\begin{array}{l}\text { Household activity; the activity on goods and services } \\
\text { produced by the household for the private consumption }\end{array}$ & 5075 & 3.0 & 14675 & 2.3 \\
\hline Total & 170934 & 100 & 623507 & 100 \\
\hline
\end{tabular}

Source: https://www.stat.gov.az/source/gender/[28].

As it is seen in the TABLE III, the number of the women entrepreneurs is very lower in comparison with the male entrepreneurs. $35,2 \%$ women entrepreneurs is engaged in agriculture, forest industry and fishing, $24.4 \%$ in commerce, repair of the means of transport, $22.5 \%$ in other fields of services, and $3.0 \%$ in household activity, and the activity on goods and services produced by the household for the private consumption.

The men contain 58,8 and the women 41,2 percent of the wage workers on economic activity types. The women are represented mostly in the fields of education, health and art. The women contained 71,4 percent of the employees working in the field of education, 76,6 percent in the field of health and social services, 63,6 percent in the field of recreation, entertainment and art (the State Statistical Committee of Azerbaijan).

No any restriction is intended for the women in the entrepreneurial activity in the legislation of the Republic of Azerbaijan, at the same time, no any extra discount and privileges are not determined in relation to the women. The economic agents are equally entitled to realize their rights without determining the gender differences and advantages in the matters such as the provision of the license and permissions along with the state registration of the entrepreneurial activity, tax obligations, auditing, the restoration of violated rights and etc. [32].

The actions taken related to the women entrepreneurs in the Strategic Road Map on national perspective of the
Republic of Azerbaijan certified under the Decree No. 1138, dated December 06, 2016 of the President of the Republic of Azerbaijan:

Action 4.4.1: The development of the stimulative mechanism on women entrepreneurship growth will review the development of the stimulative mechanism intending the crediting, taxation and other discounts for women entrepreneurs. These mechanisms will determine more perspective directions of the female employment especially in the villages, and the proper measures will be taken.

Action 4.4.2: The development of the information support for women entrepreneurship. The different actions will be taken with the purpose of provision of the information access necessary connected with the women entrepreneurship in order to provide the women entrepreneurs the information support.

Action 4.4.3: The formation of women business incubators. The formation of the special women business incubators will be reviewed with the purpose of supporting the women entrepreneurship.

Action 4.4.4: The formation of women entrepreneurship associations and professional organizations will encourage the formation of women entrepreneurial associations and professional organizations to contribute to the development of women entrepreneurship [32]. 
International Conference on Research in

Business, Management \& Economics

10-12 May, 2019 ROME, ITALY

V. RESULTS AND DISCUSSIONS

TABLE IV: GENERAL INFORMATION ON WOMEN ENTREPRENEURS PARTICIPATING IN THE QUESTIONNAIRE

\begin{tabular}{|c|c|c|c|c|c|}
\hline & & Frequency & Percent & $\begin{array}{c}\text { Valid } \\
\text { Percent }\end{array}$ & $\begin{array}{c}\text { Cumulative } \\
\text { Percent }\end{array}$ \\
\hline \multirow[t]{5}{*}{ Age } & 18-24 years old & 81 & 25,6 & 25,6 & 25,6 \\
\hline & 25-34 years old & 145 & 45,9 & 45,9 & 71,5 \\
\hline & $35-44$ years old & 48 & 15,2 & 15,2 & 86,7 \\
\hline & Older by 45 and 45 years & 42 & 13,3 & 13,3 & 100,0 \\
\hline & Total & 316 & 100,0 & 100,0 & \\
\hline \multirow[t]{5}{*}{ Education } & Secondary speciality & 33 & 10,4 & 10,4 & 10,4 \\
\hline & Complete secondary & 27 & 8,5 & 8,5 & 19,0 \\
\hline & Bachelor level & 160 & 50,6 & 50,6 & 69,6 \\
\hline & Master /Doctoral degree & 96 & 30,4 & 30,4 & 100,0 \\
\hline & Total & 316 & 100,0 & 100,0 & \\
\hline \multirow[t]{4}{*}{ Marital status } & Single & 107 & 33,9 & 33,9 & 33,9 \\
\hline & Married & 189 & 59,8 & 59,8 & 93,7 \\
\hline & Other & 29 & 6,3 & 6,3 & 100,0 \\
\hline & Total & 316 & 100,0 & 100,0 & \\
\hline \multirow{5}{*}{$\begin{array}{l}\text { Children } \\
\text { number }\end{array}$} & No children & 135 & 42,7 & 42,7 & 42,7 \\
\hline & 1 & 83 & 26,3 & 26,3 & 69,0 \\
\hline & 2 & 80 & 25,3 & 25,3 & 94,3 \\
\hline & 3 and more & 18 & 5,7 & 5,7 & 100,0 \\
\hline & Total & 316 & 100,0 & 100,0 & \\
\hline \multirow{5}{*}{$\begin{array}{l}\text { Period of } \\
\text { entrepreneurial } \\
\text { activity }\end{array}$} & $0-3$ years & 204 & 64,6 & 64,6 & 64,6 \\
\hline & 4-7 years & 67 & 21,2 & 21,2 & 85,8 \\
\hline & $8-11$ years & 23 & 7,3 & 7,3 & 93,0 \\
\hline & more than 12 years & 22 & 7,0 & 7,0 & 100,0 \\
\hline & Total & 316 & 100,0 & 100,0 & \\
\hline \multirow{6}{*}{$\begin{array}{l}\text { Monthly } \\
\text { salary? }\end{array}$} & $0-300$ azn & 76 & 24,1 & 24,1 & 24,1 \\
\hline & 301-600 azn & 65 & 20,6 & 20,6 & 44,6 \\
\hline & 601-900 azn & 50 & 15,8 & 15,8 & 60,4 \\
\hline & 901-1200 azn & 37 & 11,7 & 11,7 & 72,2 \\
\hline & 1201 azn and more & 88 & 27,8 & 27,8 & 100,0 \\
\hline & Total & 316 & 100,0 & 100,0 & \\
\hline
\end{tabular}




\section{International Conference on Research in}

\section{Business, Management \& Economics}

TABLE V: T-TEST ANALYSIS OF CHARACTERISTICS AND MARITAL STATUS OF WOMEN ENTREPRENEURS

\begin{tabular}{|ll|c|c|c|c|}
\hline & Marital status? & N & Mean & Std. Deviation & Std. Error Mean \\
\hline \multirow{2}{*}{$\begin{array}{l}\text { I am self- } \\
\text { confident }\end{array}$} & Single & 107 & 1,3364 &, 47472 &, 04589 \\
\hline \multirow{2}{*}{$\begin{array}{l}\text { I am courageous } \\
\end{array}$} & Married & 189 & 1,1640 &, 42474 &, 03090 \\
\cline { 2 - 6 } & Single & 107 & 1,4112 &, 56557 &, 05468 \\
\hline \multirow{2}{*}{$\begin{array}{l}\text { I rely on my } \\
\text { Mxperience }\end{array}$} & Single & 189 & 1,2593 &, 43939 &, 03196 \\
\hline \multirow{2}{*}{ I am diligent } & Married & 107 & 1,4112 &, 56557 &, 05468 \\
& Single & 189 & 1,5450 &, 54023 &, 03930 \\
\hline \multirow{2}{*}{ I am sociable } & Married & 107 & 1,3645 &, 48355 &, 04675 \\
& Single & 189 & 1,1640 &, 42474 &, 03090 \\
\hline & Married & 107 & 1,3364 &, 54848 &, 05302 \\
\hline
\end{tabular}

INDEPENDENT SAMPLES TEST

\begin{tabular}{|c|c|c|c|c|c|c|c|c|c|}
\hline \multirow[b]{4}{*}{$\begin{array}{l}\text { I am self- } \\
\text { confident }\end{array}$} & \multicolumn{2}{|c|}{$\begin{array}{c}\text { Levene's Test for } \\
\text { Equality of } \\
\text { Variances } \\
\end{array}$} & \multicolumn{7}{|c|}{ t-test for Equality of Means } \\
\hline & \multirow[b]{2}{*}{$\mathrm{F}$} & \multirow[b]{2}{*}{ Sig. } & \multirow[b]{2}{*}{$\mathrm{t}$} & \multirow[b]{2}{*}{ df } & \multirow{2}{*}{$\begin{array}{l}\text { Sig. (2- } \\
\text { tailed) }\end{array}$} & \multirow{2}{*}{$\begin{array}{c}\text { Mean } \\
\text { Differenc } \\
\mathrm{e} \\
\end{array}$} & \multirow{2}{*}{$\begin{array}{c}\text { Std. } \\
\text { Error } \\
\text { Differen } \\
\text { ce } \\
\end{array}$} & \multicolumn{2}{|c|}{$\begin{array}{l}\text { 95\% Confidence } \\
\text { Interval of the } \\
\text { Difference }\end{array}$} \\
\hline & & & & & & & & Lower & Upper \\
\hline & 25,501 &, 000 & $\begin{array}{l}3,214 \\
3,117 \\
\end{array}$ & $\begin{array}{r}294 \\
200,617 \\
\end{array}$ & $\begin{array}{l}, 001 \\
, 002 \\
\end{array}$ & $\begin{array}{l}, 17243 \\
, 17243 \\
\end{array}$ & $\begin{array}{l}, 05364 \\
, 05532 \\
\end{array}$ & $\begin{array}{l}, 06685 \\
, 06334 \\
\end{array}$ & $\begin{array}{l}, 27800 \\
, 28152 \\
\end{array}$ \\
\hline $\begin{array}{l}\text { I am } \\
\text { courageous }\end{array}$ & 24,679 &, 000 & $\begin{array}{l}2,570 \\
2,399 \\
\end{array}$ & $\begin{array}{r}294 \\
179,031 \\
\end{array}$ & $\begin{array}{l}, 011 \\
, 017 \\
\end{array}$ & $\begin{array}{l}, 15196 \\
, 15196 \\
\end{array}$ & $\begin{array}{l}, 05912 \\
, 06333 \\
\end{array}$ & $\begin{array}{l}, 03561 \\
, 02698 \\
\end{array}$ & $\begin{array}{l}, 26831 \\
, 27693 \\
\end{array}$ \\
\hline $\begin{array}{l}\text { I rely on my } \\
\text { experience }\end{array}$ &, 035 &, 853 & $\begin{array}{l}-2,012 \\
-1,987 \\
\end{array}$ & $\begin{array}{r}294 \\
211,909 \\
\end{array}$ & $\begin{array}{l}, 045 \\
, 048 \\
\end{array}$ & $\begin{array}{l}-, 13376 \\
-, 13376\end{array}$ & $\begin{array}{l}, 06648 \\
, 06733\end{array}$ & $\begin{array}{l}-, 26460 \\
-, 26649\end{array}$ & $\begin{array}{l}-, 00292 \\
-, 00103\end{array}$ \\
\hline I am diligent & 32,030 &, 000 & $\begin{array}{l}3,708 \\
3,578 \\
\end{array}$ & $\begin{array}{r}294 \\
197,571 \\
\end{array}$ & $\begin{array}{r}, 000 \\
, 000 \\
\end{array}$ & $\begin{array}{l}, 20046 \\
, 20046 \\
\end{array}$ & $\begin{array}{l}, 05406 \\
, 05603 \\
\end{array}$ & $\begin{array}{l}, 09407 \\
, 08996 \\
\end{array}$ & $\begin{array}{r}, 30686 \\
, 31097 \\
\end{array}$ \\
\hline I am sociable & 7,599 & ,006 & $\begin{array}{l}-1,884 \\
-1,999\end{array}$ & $\begin{array}{r}294 \\
260,071\end{array}$ & $\begin{array}{l}, 061 \\
, 047\end{array}$ & $\begin{array}{l}-, 14503 \\
-, 14503\end{array}$ & $\begin{array}{l}, 07699 \\
, 07256\end{array}$ & $\begin{array}{l}-, 29656 \\
-, 28792\end{array}$ & $\begin{array}{r}, 00650 \\
-, 00215\end{array}$ \\
\hline
\end{tabular}

In the result of this analysis, the single women entrepreneurs state that, they are self-confident, courageous and diligent. The married women entrepreneurs state that, they rely on their experience and they are sociable persons. 


\section{International Conference on Research in}

\section{Business, Management \& Economics}

TABLE VI: T TEST ANALYSIS BETWEEN THE ENTREPRENEURSHIP CHARACTERS AND THE QUESTIONS “I HAD PROBLEMS DURING MY ENTREPRENEURIAL ACTIVITY AS I WAS A WOMAN"

GROUP STATISTICS

\begin{tabular}{|ll|r|r|r|r|}
\hline & $\begin{array}{l}\text { I had problems during my } \\
\text { entrepreneurial activity as } \\
\text { I was a woman. }\end{array}$ & N & Mean & \multicolumn{1}{c|}{$\begin{array}{c}\text { Std. } \\
\text { Deviation }\end{array}$} & $\begin{array}{c}\text { Std. Error } \\
\text { Mean }\end{array}$ \\
\hline I am patient & Yes & 80 & 1,6500 &, 96914 &, 10835 \\
& No & 236 & 1,9237 & 1,09278 &, 07113 \\
\hline To take a risk & Yes & 80 & 1,4500 &, 59321 &, 06632 \\
& No & 236 & 2,0508 & 1,04655 &, 06812 \\
\hline I am courageous & Yes & 80 & 1,4000 &, 49299 &, 05512 \\
& No & 236 & 1,2754 &, 48421 &, 03152 \\
\hline I can make logical decision & Yes & 80 & 1,4000 &, 49299 &, 05512 \\
& No & 236 & 1,5593 &, 59132 &, 03849 \\
\hline
\end{tabular}

\begin{tabular}{|c|c|c|c|c|c|c|c|c|c|}
\hline \multicolumn{10}{|c|}{ INDEPENDENT SAMPLES TEST } \\
\hline \multirow{5}{*}{ I am patient } & \multicolumn{2}{|c|}{$\begin{array}{c}\text { Levene's Test for } \\
\text { Equality of } \\
\text { Variances }\end{array}$} & \multicolumn{7}{|c|}{ t-test for Equality of Means } \\
\hline & \multirow[b]{2}{*}{$\mathrm{F}$} & \multirow[b]{2}{*}{ Sig. } & \multirow[b]{2}{*}{$\mathrm{t}$} & \multirow[b]{2}{*}{$\mathrm{df}$} & \multirow{2}{*}{$\begin{array}{c}\text { Sig. } \\
(2- \\
\text { tailed) } \\
\end{array}$} & \multirow{2}{*}{$\begin{array}{c}\text { Mean } \\
\text { Difference } \\
\end{array}$} & \multirow{2}{*}{$\begin{array}{l}\text { Std. Error } \\
\text { Difference }\end{array}$} & \multicolumn{2}{|c|}{$\begin{array}{c}\text { 95\% Confidence } \\
\text { Interval of the } \\
\text { Difference } \\
\end{array}$} \\
\hline & & & & & & & & Lower & Upper \\
\hline & ,032 &, 858 & $-1,990$ & 314 &, 047 &,- 27373 & ,13753 &,- 54432 &,- 00314 \\
\hline & & & $-2,112$ & 152,262 &, 036 &,- 27373 & ,12962 &,- 52981 &,- 01765 \\
\hline To take a risk & 6,890 & ,009 & $-4,873$ & 314 & ,000 &,- 60085 &, 12329 &,- 84344 &,- 35826 \\
\hline & & & $-6,320$ & 242,788 &, 000 &,- 60085 & ,09508 &,- 78813 &,- 41357 \\
\hline I am & 5,821 & ,016 & 1,980 & 314 & ,049 &, 12458 &, 06293 & ,00076 & ,24840 \\
\hline courageous & & & 1,962 & 134,289 &, 052 &, 12458 &, 06349 &,- 00100 &, 25015 \\
\hline I can make & 7,897 &, 005 & $-2,167$ & 314 &, 031 &,- 15932 &, 07351 &,- 30395 &,- 01469 \\
\hline $\begin{array}{l}\text { logical } \\
\text { decision }\end{array}$ & & & $-2,370$ & 161,900 & 019 &,- 15932 &, 06723 &,- 29208 &,- 02657 \\
\hline
\end{tabular}

In the result of the analysis it has been determined that, the women entrepreneurs saying "I am patient, I take a risk and I can make logical decision" had not problems during their entrepreneurial activity as they were women, and the women entrepreneurs saying "I am courageous" had problems during their entrepreneurial activity as they were women. 


\section{International Conference on Research in}

Business, Management \& Economics

TABLE VII: T-TEST ANALYSIS HAS BEEN CARRIED OUT BETWEEN THE QUESTIONS “WHAT DIFFICULTIES HAVE YOU COUNTERED?” AND "DO YOU RECOMMEND OTHER WOMEN TO BE ENTREPRENEUR?"

\begin{tabular}{|c|c|c|c|c|c|}
\hline & $\begin{array}{l}\text { Do you recommend } \\
\text { other women to be } \\
\text { entrepreneur? }\end{array}$ & $\mathrm{N}$ & Mean & $\begin{array}{c}\text { Std. } \\
\text { Deviation }\end{array}$ & $\begin{array}{l}\text { Std. } \\
\text { Error } \\
\text { Mean }\end{array}$ \\
\hline \multirow[t]{2}{*}{ Unable to find a place } & Yes & 300 & 3,0567 & 1,32387 & 07643 \\
\hline & No & 16 & 4,0000 & 1,26491 &, 31623 \\
\hline \multirow[t]{2}{*}{ Inexperience } & Yes & 300 & 31133 & 114522 & 06612 \\
\hline & No & 16 & 2,0000 &, 73030 & ,18257 \\
\hline \multirow[t]{2}{*}{ Economic crisis } & Yes & 300 & 2,9733 & 1,41396 & ,08164 \\
\hline & No & 16 & 1,2500 & ,44721 & ,11180 \\
\hline
\end{tabular}

INDEPENDENT SAMPLES TEST

\begin{tabular}{|c|c|c|c|c|c|c|c|c|c|}
\hline \multirow[b]{4}{*}{$\begin{array}{l}\text { Unable to } \\
\text { find a place }\end{array}$} & \multicolumn{2}{|c|}{$\begin{array}{c}\text { Levene's Test for } \\
\text { Equality of } \\
\text { Variances }\end{array}$} & \multicolumn{7}{|c|}{ t-test for Equality of Means } \\
\hline & \multirow[b]{2}{*}{$\mathrm{F}$} & \multirow[b]{2}{*}{ Sig. } & \multirow[b]{2}{*}{$\mathrm{t}$} & \multirow[b]{2}{*}{ df } & \multirow{2}{*}{$\begin{array}{l}\text { Sig. (2- } \\
\text { tailed) }\end{array}$} & \multirow{2}{*}{$\begin{array}{c}\text { Mean } \\
\text { Difference } \\
\end{array}$} & \multirow{2}{*}{$\begin{array}{l}\text { Std. Error } \\
\text { Difference }\end{array}$} & \multicolumn{2}{|c|}{$\begin{array}{c}95 \% \text { Confidence Interval } \\
\text { of the Difference }\end{array}$} \\
\hline & & & & & & & & Lower & Upper \\
\hline &, 284 &, 595 & $\begin{array}{l}-2,783 \\
-2,900 \\
\end{array}$ & $\begin{array}{r}314 \\
16,801 \\
\end{array}$ & $\begin{array}{r}, 006 \\
, 010 \\
\end{array}$ & $\begin{array}{l}-, 94333 \\
-, 94333 \\
\end{array}$ & $\begin{array}{l}, 33897 \\
, 32533 \\
\end{array}$ & $\begin{array}{r}-1,61028 \\
-1,63035 \\
\end{array}$ & $\begin{array}{l}-, 27639 \\
-, 25632 \\
\end{array}$ \\
\hline $\begin{array}{l}\text { Inexperienc } \\
\mathrm{e}\end{array}$ & 6,587 &, 011 & $\begin{array}{l}3,844 \\
5,734 \\
\end{array}$ & $\begin{array}{r}314 \\
19,176 \\
\end{array}$ & $\begin{array}{r}, 000 \\
, 000 \\
\end{array}$ & $\begin{array}{l}1,11333 \\
1,11333 \\
\end{array}$ & $\begin{array}{l}, 28965 \\
, 19418 \\
\end{array}$ & $\begin{array}{l}, 54344 \\
, 70717 \\
\end{array}$ & $\begin{array}{l}1,68323 \\
1,51950 \\
\end{array}$ \\
\hline $\begin{array}{l}\text { Economic } \\
\text { crisis }\end{array}$ & 25,735 &, 000 & $\begin{array}{r}4,856 \\
12,449\end{array}$ & $\begin{array}{r}314 \\
34,762\end{array}$ & $\begin{array}{l}, 000 \\
000\end{array}$ & $\begin{array}{l}1,72333 \\
1,72333\end{array}$ & $\begin{array}{l}, 35491 \\
, 13844\end{array}$ & $\begin{array}{l}1,02503 \\
1,44223\end{array}$ & $\begin{array}{r}2,42164 \\
2,00444\end{array}$ \\
\hline
\end{tabular}

It is seen in the T-test analysis that, the women entrepreneurs recommending other women to be engage in the entrepreneurial activity come across with the economic crisis and inexperience. At the same time, the women entrepreneurs encountering with the problem of inability to find a place does not recommend other women to be engage in the entrepreneurial activity. 


\section{International Conference on Research in}

\section{Business, Management \& Economics}

TABLE VIII: ANOVA ANALYSIS OF THE AGES WITH THE PROBLEMS CONFRONTED BY THE WOMEN ENTREPRENEURS

\begin{tabular}{|c|c|c|c|c|c|}
\hline & $\begin{array}{l}\text { Sum of } \\
\text { Squares }\end{array}$ & $\mathrm{df}$ & $\begin{array}{c}\text { Mean } \\
\text { Square }\end{array}$ & $\mathrm{F}$ & Sig. \\
\hline $\begin{array}{l}\text { I have not been } \\
\text { countered with any } \\
\text { difficulty }\end{array}$ & $\begin{array}{l}45,604 \\
515,798 \\
561,402\end{array}$ & $\begin{array}{l}3 \\
312 \\
315\end{array}$ & $\begin{array}{l}15,201 \\
1,653\end{array}$ & 9,195 & ,000 \\
\hline Family dissatisfaction & $\begin{array}{l}24,304 \\
492,443 \\
516,747 \\
\end{array}$ & $\begin{array}{l}3 \\
312 \\
315\end{array}$ & $\begin{array}{l}8,101 \\
1,578\end{array}$ & 5,133 &, 002 \\
\hline $\begin{array}{l}\text { Husband's } \\
\text { dissatisfaction }\end{array}$ & $\begin{array}{l}8,669 \\
\\
380,521 \\
389,190 \\
\end{array}$ & $\begin{array}{l}3 \\
312 \\
315 \\
\end{array}$ & $\begin{array}{l}2,890 \\
1,220\end{array}$ & 2,369 &, 071 \\
\hline $\begin{array}{l}\text { Lack of financial } \\
\text { means }\end{array}$ & $\begin{array}{l}75,187 \\
490,484 \\
565,671\end{array}$ & $\begin{array}{l}3 \\
312 \\
315\end{array}$ & $\begin{array}{l}25,062 \\
1,572\end{array}$ & 15,942 & ,000 \\
\hline $\begin{array}{l}\text { Thought of failure in } \\
\text { business }\end{array}$ & $\begin{array}{l}55,009 \\
478,371 \\
533,380 \\
\end{array}$ & $\begin{array}{l}3 \\
312 \\
315\end{array}$ & $\begin{array}{l}18,336 \\
1,533\end{array}$ & 11,959 &, 000 \\
\hline Unable to find a place & $\begin{array}{l}103,618 \\
457,935 \\
561,554 \\
\end{array}$ & $\begin{array}{l}3 \\
312 \\
315\end{array}$ & $\begin{array}{l}34,539 \\
1,468\end{array}$ & 23,532 & ,000 \\
\hline $\begin{array}{l}\text { Impossibility to } \\
\text { receive information }\end{array}$ & $\begin{array}{l}63,707 \\
480,787 \\
544,494 \\
\end{array}$ & $\begin{array}{l}3 \\
312 \\
315 \\
\end{array}$ & $\begin{array}{l}21,236 \\
1,541\end{array}$ & 13,781 & 000 \\
\hline $\begin{array}{l}\text { Difficulty and } \\
\text { confusion of } \\
\text { documentation affairs }\end{array}$ & $\begin{array}{l}94,857 \\
438,570 \\
533,427 \\
\end{array}$ & $\begin{array}{l}3 \\
312 \\
315\end{array}$ & $\begin{array}{l}31,619 \\
1,406\end{array}$ & 22,494 & ,000 \\
\hline Inexperience & $\begin{array}{l}22,149 \\
396,825 \\
418,975\end{array}$ & $\begin{array}{l}3 \\
312 \\
315\end{array}$ & $\begin{array}{l}7,383 \\
1,272\end{array}$ & 5,805 & ,001 \\
\hline $\begin{array}{l}\text { Not to find time } \\
\text { because of } \\
\text { housekeeping }\end{array}$ & $\begin{array}{l}50,410 \\
533,311 \\
583,722 \\
\end{array}$ & $\begin{array}{l}3 \\
312 \\
315 \\
\end{array}$ & $\begin{array}{l}16,803 \\
1,709\end{array}$ & 9,830 &, 000 \\
\hline Economic crisis & $\begin{array}{l}42,066 \\
603,833 \\
645,899\end{array}$ & $\begin{array}{l}3 \\
312 \\
315\end{array}$ & $\begin{array}{l}14,022 \\
1,935\end{array}$ & 7,245 & ,000 \\
\hline
\end{tabular}

The women 40 years old or older stated that, they do not encounter difficulty and they had no problem in finding a place rather than the other 3 groups.

The women 25-34 years old have chosen the answers such as - Family dissatisfaction, the lack of financial means, unability to find a place, Impossibility to receive information and difficulty and Confusion of documentation affairs rather than the other 3 groups. 


\section{International Conference on Research in}

Business, Management \& Economics

TABLE IX: ANOVA ANALYSIS HAS BEEN CARRIED OUT AMONG THE WOMEN ENTREPRENEURS SAYING “I BEGAN THE ENTREPRENEURIAL ACTIVITY BECAUSE OF UNEMPLOYMENT" IN RESPONSE TO THE QUESTION “IN WHAT AREA ARE YOU ENGAGED IN ENTREPRENEURİAL ACTIVITY?”

ANOVA

\begin{tabular}{|l|r|r|r|r|r|}
\hline & $\begin{array}{r}\text { Sum of } \\
\text { Squares }\end{array}$ & df & $\begin{array}{r}\text { Mean } \\
\text { Square }\end{array}$ & F & Sig. \\
\hline Between Groups & 58,868 & 7 & 8,410 & 6,301 &, 000 \\
Within Groups & 411,106 & 308 & 1,335 & & \\
Total & 469,975 & 315 & & & \\
\hline
\end{tabular}

\begin{tabular}{|c|c|c|c|c|c|c|}
\hline & \multirow{2}{*}{$\begin{array}{l}\text { In what area do you engage in } \\
\text { entrepreneurial activity? }\end{array}$} & \multirow[b]{2}{*}{$\mathrm{N}$} & \multicolumn{4}{|c|}{ Subset for alpha $=0.05$} \\
\hline & & & 1 & 2 & 3 & 4 \\
\hline \multirow{9}{*}{$\begin{array}{l}\text { Tukey } \\
\text { HSD }^{\mathrm{a}, \mathrm{b}}\end{array}$} & Health & 15 & 2,5333 & & & \\
\hline & Other & 68 & 3,2353 & 3,2353 & & \\
\hline & Dress-goods industry & 78 & 3,3590 & 3,3590 & 3,3590 & \\
\hline & Service & 82 & & 3,6585 & 3,6585 & 3,6585 \\
\hline & Tourism & 16 & & 3,7500 & 3,7500 & 3,7500 \\
\hline & Construction & 16 & & 4,0000 & 4,0000 & 4,0000 \\
\hline & Agriculture & 16 & & & 4,3750 & 4,3750 \\
\hline & Education & 25 & & & & 4,4000 \\
\hline & Sig. & & ,211 &, 302 &, 051 &, 342 \\
\hline \multirow[t]{9}{*}{ Scheffe $e^{a, b}$} & Health & 15 & 2,5333 & & & \\
\hline & Other & 68 & 3,2353 & 3,2353 & & \\
\hline & Dress-goods industry & 78 & 3,3590 & 3,3590 & & \\
\hline & Service & 82 & 3,6585 & 3,6585 & & \\
\hline & Tourism & 16 & 3,7500 & 3,7500 & & \\
\hline & Construction & 16 & & 4,0000 & & \\
\hline & Agriculture & 16 & & 4,3750 & & \\
\hline & Education & 25 & & 4,4000 & & \\
\hline & Sig. & &, 069 & ,099 & & \\
\hline
\end{tabular}

The majority of the women entrepreneurs saying that, they began the entrepreneurship because of unemployment work in the field of agriculture. At the same time, the women entrepreneurs working in the field of education because of unemployment prevail the women entrepreneurs working in the field of dress-goods industry. And the women working in service industry because of unemployment prevail the women working in the field of health. 


\section{International Conference on Research in \\ Business, Management \& Economics}

\section{TABLE X: ANOVA ANALYSIS ON ENTREPRENEURIAL ACTIVITY BEING ENGAGED IN BY THE WOMEN ENTREPRENEURS CONFRONTING WITH THE ECONOMIC CRISIS.}

ANOVA

ECONOMIC CRISIS

\begin{tabular}{|l|r|r|r|r|r|}
\hline & Sum of Squares & df & \multicolumn{1}{|c|}{ Square } & F & Sig. \\
\hline Between Groups & 64,854 & 7 & 9,265 & 4,911 &, 000 \\
Within Groups & 581,044 & 308 & 1,887 & & \\
Total & 645,899 & 315 & & & \\
\hline
\end{tabular}

\begin{tabular}{|c|c|c|c|c|c|}
\hline \multicolumn{6}{|c|}{ ECONOMIC CRİIS } \\
\hline & \multirow{2}{*}{$\begin{array}{l}\text { In what area do you } \\
\text { engage in entrepreneurial } \\
\text { activity? }\end{array}$} & \multirow[b]{2}{*}{$\mathrm{N}$} & \multicolumn{3}{|c|}{ Subset for alpha $=0.05$} \\
\hline & & & 1 & 2 & 3 \\
\hline \multirow{9}{*}{$\begin{array}{l}\text { Tukey } \\
\text { HSD }^{\mathrm{a}, \mathrm{b}}\end{array}$} & Agriculture & 16 & 1,6250 & & \\
\hline & Health & 15 & 2,0667 & 2,0667 & \\
\hline & Construction & 16 & 2,2500 & 2,2500 & 2,2500 \\
\hline & Dress-goods industry & 78 & 2,7949 & 2,7949 & 2,7949 \\
\hline & Other & 68 & & 2,8824 & 2,8824 \\
\hline & Tourism & 16 & & 3,0000 & 3,0000 \\
\hline & Education & 25 & & 3,2400 & 3,2400 \\
\hline & Service & 82 & & & 3,3659 \\
\hline & Sig. & &, 067 &, 065 &, 096 \\
\hline \multirow[t]{9}{*}{ Scheffe $\mathrm{e}^{\mathrm{a}, \mathrm{b}}$} & Agriculture & 16 & 1,6250 & & \\
\hline & Health & 15 & 2,0667 & 2,0667 & \\
\hline & Construction & 16 & 2,2500 & 2,2500 & \\
\hline & Dress-goods industry & 78 & 2,7949 & 2,7949 & \\
\hline & Other & 68 & 2,8824 & 2,8824 & \\
\hline & Tourism & 16 & 3,0000 & 3,0000 & \\
\hline & Education & 25 & & 3,2400 & \\
\hline & Service & 82 & & 3,3659 & \\
\hline & Sig. & & , 105 & ,156 & \\
\hline
\end{tabular}

According to the result of the anova analysis, the economic crisis has caused less problem for the women entrepreneurs working in the dress-goods industry rather than the women entrepreneurs working in service industry, but it influenced more to the entrepreneurs working in health industry. The economic crisis influenced more to the education industry rather than the agricultural industry. Generally, the women entrepreneurs who suffered from the economic crisis least of all are the entrepreneurs working in the agricultural industry. 
International Conference on Research in

Business, Management \& Economics

10-12 May, 2019 ROME, ITALY

TABLE XI: ANOVA ANALYSIS HAS BEEN CARRIED OUT BETWEEN THE WOMEN ENTREPRENEURS ASKING THE QUESTION "HOW MANY CHILDREN DO YOU HAVE?" AND THE QUESTION ANSWERED AS “I AM COURAGEOUS, I AM RESPONSIBLE, AND I RELY ON MY EXPERIENCE".

\begin{tabular}{l|r|r|r|c|c|} 
I AM COURAGEOUS & ANOVA \\
\hline & Sum of Squares & df & Mean Square & F & Sig. \\
\hline Between Groups & 4,574 & 3 & 1,525 & 6,732 &, 000 \\
Within Groups & 70,651 & 312 &, 226 & & \\
Total & 75,225 & 315 & & & \\
\hline
\end{tabular}

I AM RESPONSIBLE

\begin{tabular}{|l|r|r|r|r|r|}
\hline & \multicolumn{1}{|c|}{$\begin{array}{l}\text { Sum of } \\
\text { Squares }\end{array}$} & df & $\begin{array}{r}\text { Mean } \\
\text { Square }\end{array}$ & \multicolumn{1}{c|}{ F } & \multicolumn{1}{|c|}{ Sig. } \\
\hline Between & 5,097 & 3 & 1,699 & 8,671 &, 000 \\
Groups & 61,140 & 312 &, 196 & & \\
Within Groups & 66,237 & 315 & & & \\
Total & & & \\
\hline
\end{tabular}

\begin{tabular}{|l|r|r|r|r|r|}
\hline \multicolumn{1}{|c|}{ I RELY ON MY EXPERIENCES } \\
& \multicolumn{1}{|c|}{$\begin{array}{l}\text { Sum of } \\
\text { Squares }\end{array}$} & \multicolumn{1}{c|}{ df } & $\begin{array}{r}\text { Mean } \\
\text { Square }\end{array}$ & \multicolumn{1}{c|}{ F } & \multicolumn{1}{c|}{ Sig. } \\
\hline Between Groups & 6,453 & 3 & 2,151 & 5,592 &, 001 \\
Within Groups & 120,013 & 312 &, 385 & & \\
Total & 126,465 & 315 & & & \\
\hline
\end{tabular}

The women having 3 or more children have stated that, they believe their experience rather than others, while the women entrepreneurs having no children claim that, they are more responsible and courageous rather than the women with 1 and 2 children.

TABLE XII: ANOVA ANALYSIS HAS BEEN CARRIED OUT IN THE QUESTIONNAIRE BETWEEN THE QUESTIONS ABOUT "YOUR EDUCATION" AND "SELF-CONFIDENCE".

I AM SELF-CONFIDENT ANOVA
\begin{tabular}{|l|r|r|r|c|c|}
\hline & Sum of Squares & df & Mean Square & F & Sig. \\
\hline Between Groups &, 847 & 3 &, 282 & 1,368 &, 253 \\
Within Groups & 64,353 & 312 &, 206 & & \\
Total & 65,199 & 315 & & & \\
\hline
\end{tabular}

19

\section{www.icrbme.org} info@icrbme.org 
International Conference on Research in

Business, Management \& Economics

10-12 May, 2019 ROME, ITALY

\begin{tabular}{|c|c|c|c|}
\hline & \multirow[b]{2}{*}{ Education? } & \multirow[b]{2}{*}{$\mathrm{N}$} & Subset for alpha $=0.05$ \\
\hline & & & 1 \\
\hline \multirow[t]{5}{*}{ Tukey HSD ${ }^{\mathrm{a}, \mathrm{b}}$} & Complete secondary & 27 & 1,1111 \\
\hline & Secondary speciality & 33 & 1,1515 \\
\hline & Master/ Doctoral degree & 96 & 1,2500 \\
\hline & Bachelor level & 160 & 1,2688 \\
\hline & Sig. & &, 329 \\
\hline \multirow[t]{5}{*}{ Scheffe $e^{a, b}$} & Complete secondary & 27 & 1,1111 \\
\hline & Secondary speciality & 33 & 1,1515 \\
\hline & Master/ Doctoral degree & 96 & 1,2500 \\
\hline & Bachelor level & 160 & 1,2688 \\
\hline & Sig. & & ,414 \\
\hline
\end{tabular}

The women entrepreneurs with secondary education participating in the questionnaire have stated that, they

are less courageous in comparison with other women.

TABLE XII: ANOVA ANALYSIS OF MONTHLY INCOME AND THE ENCOUNTERED DIFFİCULTIES OF THE WOMEN ENTREPRENEURS

\begin{tabular}{|l|r|r|r|r|r|}
\hline & Aum of Squares & df & Mean Square & F & Sig. \\
\hline I have not encountered & 72,063 & 4 & 18,016 & 11,450 & \multirow{2}{*}{, 000} \\
difficulties & 489,339 & 311 & 1,573 & & \\
& 561,402 & 315 & & & \\
\hline
\end{tabular}

\begin{tabular}{|c|c|c|c|c|c|c|}
\hline & \multirow[b]{2}{*}{ Monthly salary? } & \multirow[b]{2}{*}{$\mathrm{N}$} & \multicolumn{4}{|c|}{ Subset for alpha $=0.05$} \\
\hline & & & 1 & 2 & 3 & 4 \\
\hline \multirow{6}{*}{$\begin{array}{l}\text { Tukey } \\
\text { HSD }^{\mathrm{a}, \mathrm{b}}\end{array}$} & $0-300$ azn & 76 & 2,7895 & & & \\
\hline & 301-600 azn & 65 & 2,9385 & 2,9385 & & \\
\hline & 601-900 azn & 50 & & 3,5600 & 3,5600 & \\
\hline & 1201 azn and more & 88 & & & 3,6364 & 3,6364 \\
\hline & 901-1200 azn & 37 & & & & 4,2162 \\
\hline & Sig. & & ,969 & ,063 & ,998 & ,098 \\
\hline \multirow[t]{6}{*}{ Scheffe $e^{a, b}$} & $0-300$ azn & 76 & 2,7895 & & & \\
\hline & $301-600$ azn & 65 & 2,9385 & 2,9385 & & \\
\hline & 601-900 azn & 50 & & 3,5600 & 3,5600 & \\
\hline & 1201 azn and more & 88 & & 3,6364 & 3,6364 & \\
\hline & 901-1200 azn & 37 & & & 4,2162 & \\
\hline & Sig. & & ,982 & ,066 & ,099 & \\
\hline
\end{tabular}




\section{International Conference on Research in}

\section{Business, Management \& Economics}

The women entrepreneurs earning 0-300 azn monthly income stated that, they had encountered with less difficulties. And the women entrepreneurs earning 600-
ICRBME

\section{0-12 May, 2019 ROME, ITALY}

900 azn monthly income stated that, they had encountered with more difficulties.

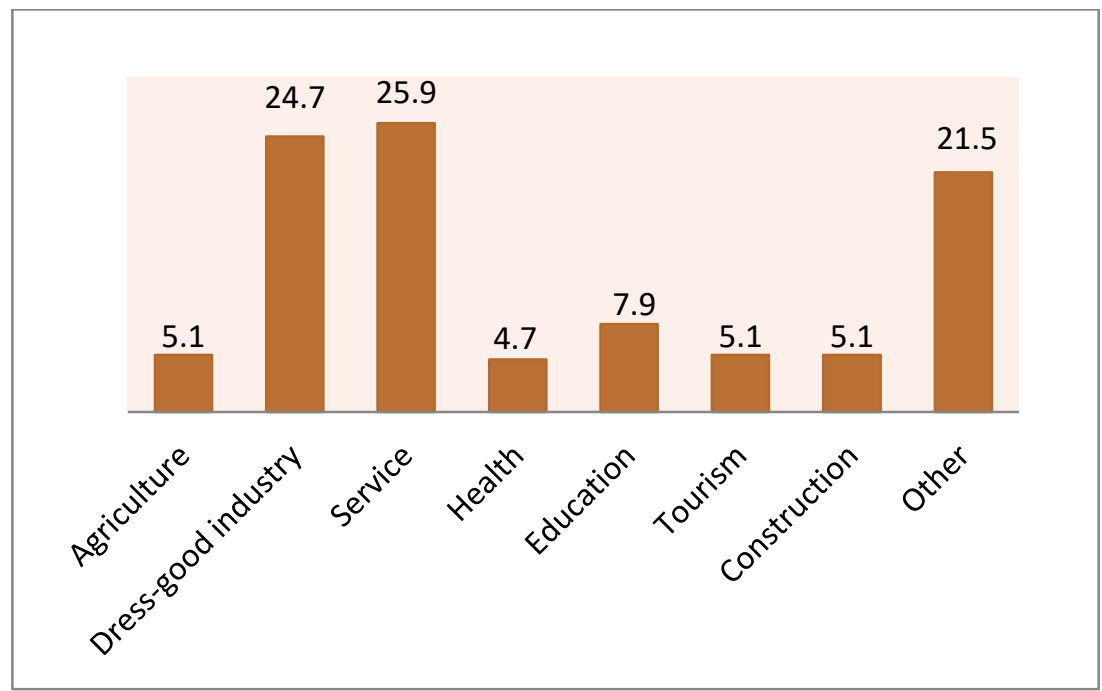

Figures 1. In what area do you engage in entrepreneurial activity? (in percent)

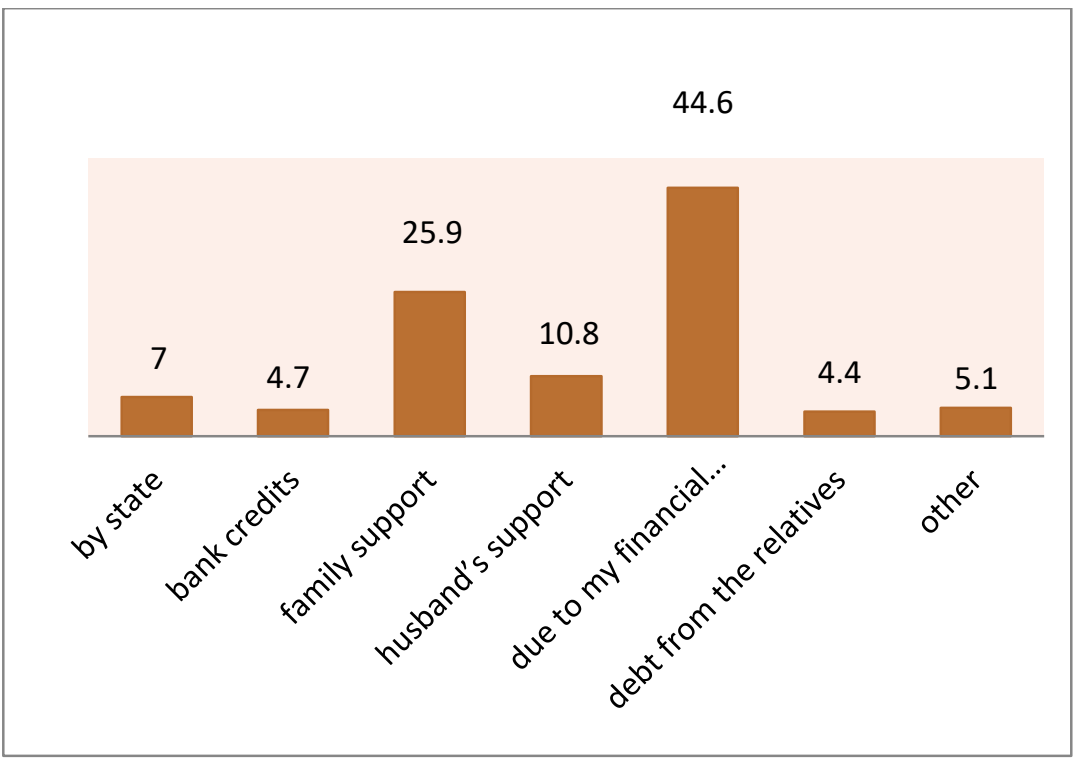

Figures 2. Where did you get capital while building your business? (in percent) 


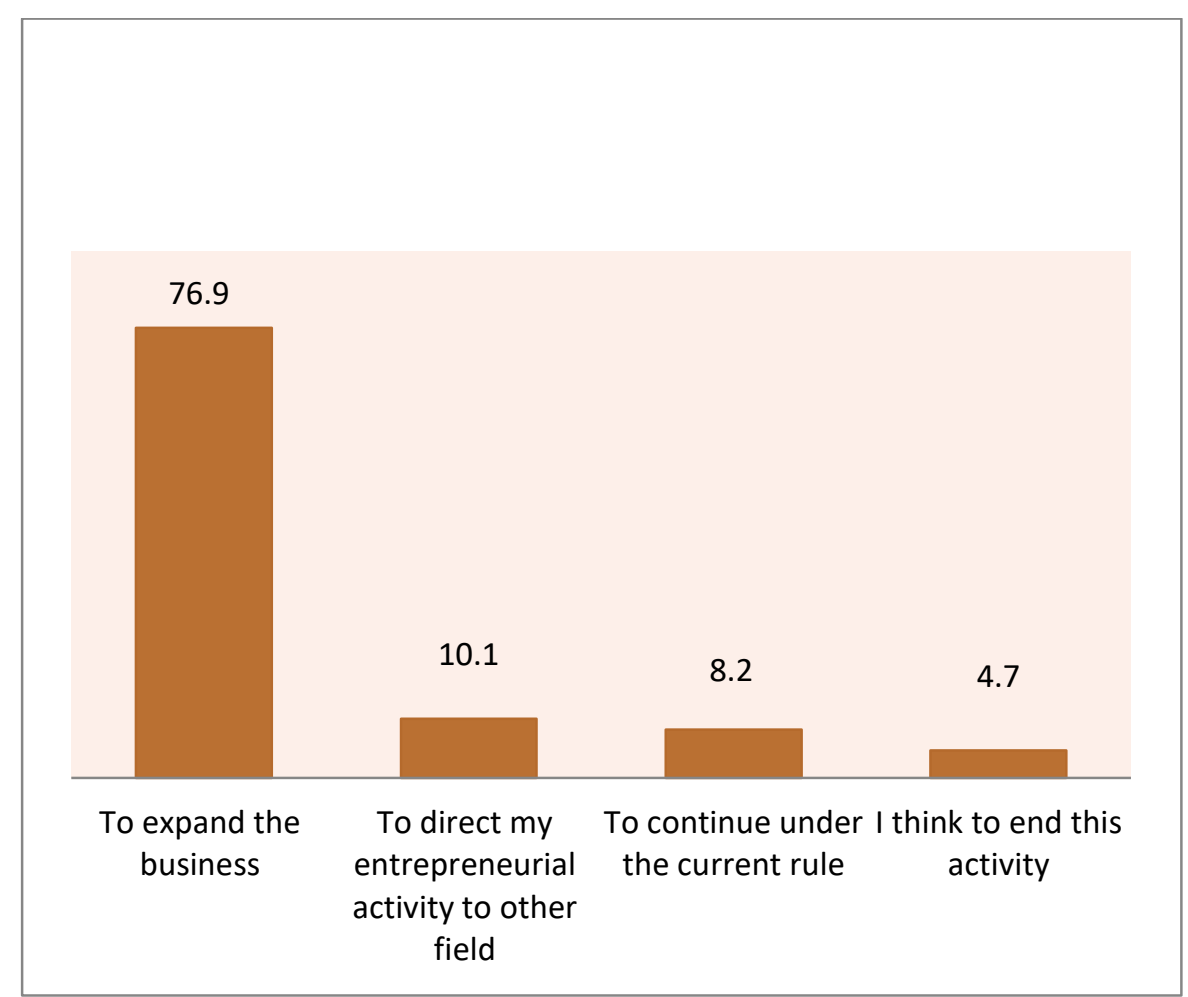

Figures 3. What is your future plans about your current entrepreneurial activity? (in percent)

\section{CONCLUSIONAND RECOMMENDATIONS}

Women's entrepreneurship continues to grow worldwide. As per the GEM (2016) report on women's entrepreneurship and entrepreneurial activity among women increased in total for 10 per cent, and it led to narrowing the gender gap by 5 per cent over 2014 .

There is no any legal difference between the women and men in the laws of the Independent Republic of Azerbaijan, no any special prohibition or discount is applied for women as they are women when they begin the entrepreneurial activity officially because of them. If we take into account

that, the number of the female entrepreneurs is lower $58 \%$ than the male entrepreneurs according to the reports of the State Statistical Committee of Azerbaijan, we can see that, the women containing the half of the country population and having the potential act very little in the entrepreneurship. We can see that, the majority of women entrepreneurs work in the field of Agriculture and Commerce.

The signs of influence of 70 years Soviet Union still remain in the economy. Although entrepreneurial activity has developed in our country, we need the fast development of women entrepreneurship, the formation of entrepreneurial thought, entrepreneurial culture, and the competition culture. This stereotype remaining from the past was the main factor preventing the women's engaging in entrepreneurship, so it has been considered as the negative case by the society. But today we see the women beginning newly the entrepreneurial activity, their desire to join the economy. 316 respondents have been participated in the questionnaire applied among the women entrepreneurs acting in Azerbaijan, and during the analysis we researched that, the majority of women began the entrepreneurial activity 0-3 years, and a lot of them were satisfied with it, and recommended other women to be engage in entrepreneurial activity. During the analysis we also researched that, more than $81 \%$ of the women entrepreneurs have been studied in higher educational institutions, more than $74 \%$ do not encountered the difficulties as they are women. $29,4 \%$ from 316 women stated that, they have not encountered with any difficulties, but $21,2 \%$ had problems because of family dissatisfaction, $50,3 \%$ because of lack of financial means, $31,9 \%$ because of impossibility to receive information, $33,2 \%$ because of difficulty of documentation affairs, $33,6 \%$ because of inexperience, $43 \%$ because of economic crisis, and $43,7 \%$ because of thought of failure in business. 50,3\% women have noted the lack of their financial means, and their families have supported them $(25,9 \%)$ when they began the entrepreneurial activity, and 44,6\% stated that, they have built a business due to their financial means. $39,6 \%$ stated that, they have worked in the private sector, $24,7 \%$ 


\section{International Conference on Research in}

\section{Business, Management \& Economics}

in state sector, $10,1 \%$ were housewife, $8,9 \%$ were looking for job, and $15,5 \%$ have studied before the entrepreneurial activity. $78,5 \%$ of the women participating in the questionnaire stated that, they have directed to this field because of "flexible time" in the entrepreneurial activity, $21,6 \%$ because of unemployment, $79,4 \%$ because of desire not working under the direction of anybody.

The offers given in the article for the prevention of the issues after analyzing the existing state of women entrepreneurs and the issues they encountered:

1. The expansionary actions should be taken connected with the women entrepreneurship. The special legislation should be prepared by the state. The plans about the women entrepreneurship in the Strategic road map of the Republic of Azerbaijan should be expanded and its application should be speeded-up.

2. The public awareness campaigns should be realized in order to increase the spirit of entrepreneurship in women. So, the active projects should be realized in the universities, secondary schools, as well as, in the civil societies (NGO).

3. Generally, different credits are extended connected with the entrepreneurship, but if the special discounts will be applied for the women entrepreneurs, it will push the speedy development of this field.

4. The former traditions, the influence of the set of mind on women should be decreased, the definite plan of actions should be prepared in order the parents should not lay obstacles for their children's engaging in entrepreneurial activity.

5. With the purpose of the institutional activity of the women entrepreneurship, it is necessary to offer special opportunities in order to supply them the business services.

6. The trainings should be realized in the regions with the purpose of increasing the number of women entrepreneurs in other fields besides the agriculture.

7. The supporting programs should be organized for rejoining to the work environment of the entrepreneurs withdrawn from the entrepreneurship after a delivery of a child birth, and for their active role in the economy.

\section{REFERENCES}

[1] GEM (2015), "Global Entrepreneurship Monitor: Women's Entrepreneurship 2015/2016 Report”, available at:

https://www.gemconsortium.org/report/49480

[2] Acs Z. J. 2006 How is Entrepreneurship Good for Economic Growth? Innovations 1(1),(97-107)

\section{ICRBME}

\author{
10-12 May, 2019 ROME, ITALY
}

https://www.mitpressjournals.org/doi/pdf/10.1162/itgg. 2006.1.1.97

[3] Krakauer, P. V. de C., de Moraes, G. H. S. M. Coda, R., \& Berne, D. de F. (2018). Brazilian women's entrepreneurial profile and intention. International Journal of Gender and Entrepreneurship. doi:10.1108/ijge-04-2018-0032

[4] Dana, L.P. (2005) When Economies Change Hands: A Survey of Entrepreneurship in the Emerging Markets of Europe from the Balkans to the Baltic States, International Business Press, Binghamton, New York, reprinted (2010) Routledge, New York \& Oxford.

[5] Audretsch, D.B., Keilbach, M.C. and Lehmann, E.E. (2006), "Entrepreneurship and economic growth", Strategic Entrepreneurship Journal, Vol. 1 No. 12, pp. 745-752, available at: http://doi.org/ 10.1002/se

[6]Baumol, W.J. and Strom, R.J. (2007), "Entrepreneurship and economic growth", Strategic Entrepreneurship Journal, Vol. 1 Nos 3/4, pp. 233-237, available at: http://doi.org/10.1002/se

[7] Berg, N.G. (1997), "Gender, place and entrepreneurship", Entrepreneurship and Regional Development, Vol. 9 No. 3, pp. 259-268.

[8] Kelley, D.J., Bosma, N. and Amoros, J.E. (2010), Global Entrepreneurship Monitor: 2010 Global Report, Universidad del Desarrollo, Babson College, Santiago, Chile, Babson Park, MA.

[9]Endres, A.M. and Woods, C.R. (2006), "Modern theories of entrepreneurial behavior: a comparison and appraisal”, Small Business Economics, Vol. 26 No. 2, pp. 189-202, available at: https://doi:10.1007/ s11187-0045608-7

[10] Allen, I.E. Langowitz, N. and Minniti, M. (2007), "The 2006 global entrepreneurship monitor special topic report: women in entrepreneurship", available at: www.babson.edu/Academics/centers/blankcenter/global -research/gem/Documents/gem-2006-womenentrepreneurship-report.pdf (accessed 25 May 2018)

[11] Lechman, E., Okonowicz, A. (2013), Are Women Important for Economic Development?, Corporate Social Responsibility and Women's Entrepreneurship Around the Mare Balticum, 310.

[12] Brush, C.G. (2017), "How women entrepreneurs are transforming economies and communities", Forbes, available

at: www.forbes.com/sites/laurelmoglen/2017/03/29/matthe w-rodriguez-makes-the-toughjob-of-teaching-writingeasier/\#17a050fb7ad6 (accessed 30 March 2017).

[13] Meyskens, M. Elaine Allen, I. and Brush, C.G. (2011), "Human capital and hybrid ventures", pp. 51-72, available

at: 


\section{International Conference on Research in}

\section{Business, Management \& Economics}

www.emeraldinsight.com/doi/10.1108/S10747540\%282011\%290000013007 (accessed 8 January 2018).

[14] Yunus, M. (2007), “The nobel prize 2006 nobel lecture", Law and Business Review of the Americas, Vol. 13 No. 2, pp. 267-275.

[15] Court, K.L. (2012), "Mapping the economic contribution of women entrepreneurs", International Journal of Business and Social Science, Vol. 3 No. 1, available

http://ijbssnet.com/journals/Vol_3_No_1_January_2012 /14.pdf (accessed 31 May 2018).

[16] Brush, C.G., Carter, N., Gatewood, E., Greene, P. and Hart, M. (2001), "An investigation of women-led firms and venture capital investment", Report prepared for the US Small Business Administration, Office of Advocacy and the National Women's Business Council.

[17] Marlow, S. and Patton, D. (2005), "All credit to men, entrepreneurship, finance and gender", Entrepreneurship Theory and Practice, Vol. 29 No. 6, pp. 699-716.

GEM (2016), "Global Entrepreneurship Monitor: Women's Entrepreneurship 2016/2017 Report", available at: http://gemconsortium.org/report/49860

[18]LeylaSarfaraz, NezameddinFaghih and ArmaghanAsadiMajd(2014),-The relationship between women entrepreneurship and genderequalityll Journal of Global Entrepreneurship Research, 2:6 doi:10.1186/2251-7316-2-6.

[19] Jennifer E. Jennings (University of AlbertaSchool Of Business), Candida G. Brush(Babson College) (2013), - Research on WomenEntrepreneurs: Challenges to (and from) the Broader EntrepreneurshipLiterature?|| Vol. 7, No. 1, 661-713.

[20] Ekesionye E. N and Okolo A. N5 January, 2012, - Women empowerment and participation in economic activities: Indispensabletools for self-reliance and development of Nigerian societyll [Department of Educational Foundations, Faculty of Education, University of Nigeria, Nsukka, Nigeria]. Educational Research and Review Vol. 7(1), pp. 10-18.

[21] Syed Shah Alam (Corresponding author), MohdFauziMohdJani, Nor Asiah Omar (May 2011), -An Empirical Study of SuccessFactors of Women Entrepreneurs in Southern Region in Malaysial, International Journal of Economics and Finance Vol. 3, No. 2.

https://static.president.az/pdf/38542.pdf

\section{ICRBME}

\author{
10-12 May, 2019 ROME, ITALY
}

[22] Hackler, Darrene; Harpel, Ellen and Mayer, Heike, (2008), - Human Capital and Women's Business Ownershipl, Arlington, Office of Advocacy U.S. Small Business Administration, August 2006, VA 22201 [74], No. 323

[23] Debra Efroymson, Buddhadeb Biswas, and ShakilaRuma (September 2007), -The Economic Contribution of Women in BangladeshThrough their Unpaid Laborll,Analysis and report writing,WBB TrustHealthBridgeDhaka.

[24] C. Mirjam van Praag, Peter H. Versloot, (August 2007), - What Is the Value of Entrepreneurship?॥.

[25] Glen Cain's (1966), - Married Women in the Labour Force: an Economic Analysis\|, University of Chicago Press, Chicago.

[26] Torch Burch (Nov 18th 2013), - Why the world needs women entrepreneurs\|, http://www.economist.com/news/21589133.

[27] Tambunan, Tulus, (2009), Women entrepreneurship in Asian developing countries: Their development and main constraints,Journal of Development and Agricultural Economics Vol. 1(2), Page No. 027-040.the glass ceiling. Thousand Oaks, CA: Sage

[28] Azərbaycan Dövlət Statistika Komitəsi https://www.stat.gov.az/source/labour/

[29] Azərbaycanda qadin sahibkarliğin inkişafi milli hesabat- BӘT-İN "AZӘRBAYCAN VӘ GÜRCÜSTANDA İŞӘGÖTÜRӘNLӘR TOŞKILATLARI VASITOSİLO QADIN SAHIBKARLIĞIN İNKIŞAFI" LAYİHӘSI http://genderaz.org/doc/az/development/economic/womanenterpreneers-az.pdf

[30] Azərbaycan Dövlət İqtisadiyyat Nazirliyi 2014 https://www.economy.gov.az/article/azda-sahibinkishaf-tar/21410

[31] Ahl, H. (2006), "Why research on women entrepreneurs needs new directions?", Entrepreneurship Theory and Practice, Vol. 30 No. 5, pp. 595-621, available at: https://doi:10.1111/j.15406520.2006.00138.x

[32] Azərbaycan Respublikasının milli iqtisadiyyat perspektivi üzrə Strateji Yol Xəritəsi 